\title{
PRILOG ANALIZI DIGITALIZACIJE POSLOVANJA PREDUZEĆA U SRBIJI
}

\section{CONTRIBUTION TO ANALYSIS OF THE DIGITALIZATION OF THE COMPANY'S OPERATIONS IN SERBIA}

\section{Dušan Regodić}

Poslovni i pravni fakultet, Univerzitet Union "Nikola Tesla", Beograd, Srbija

\section{Aleksandar Matić}

Poslovni i pravni fakultet, Univerzitet Union “Nikola Tesla”, Beograd, Srbija

\section{Radomir Regodić}

Zavod za izdavanje udžbenika, Beograd

\section{Andrijana Živić}

Poslovni i pravni fakultet, Univerzitet Union “Nikola Tesla”, Beograd.

OMESTE

JEL kategorija rada: D83, L15, L86

\section{Apstrakt}

Digitalizacija ubrzano donosi promene i transformiše naše živote, ekonomiju i društvo u celini. Nove tehnologije doprinose efikasnijem poslovanju, napretku zajednice i kao takve predstavljaju osnovu da svi naši partneri iz privatnog i javnog sektora mogu da idu u korak sa savremenim tokovima globalnog tržišta, odnosno da učestvuju u onome što se naziva digitalna ekonomija. Predmet ovog rada je primena informaciono-komunikacionih tehnologija (IKT) u poslovanju preduzeća u Srbiji. Cilj rada je da analizira primene IKT analizom različitih pokazatelja. Polazna pretpostavka je da su IKT ključni faktor za povećanje ekonomske efikasnosti, ukidanja barijera, stvaranju novih poslovnih mogućnosti geografske decentralizacije i prilagođavanja preduzeća novim uslovima poslovanja. Za analizu korišćeni su najnoviji podaci relevantnih domaćih i međunarodnih institucija. U prvom delu rada opisani su savremeni globalni tehnološki trendovi i njihov uticaj na poslovanje preduzeća i načini merenja spremnosti zemalja za korišćenje IKT. U drugom delu rada analizirano je kretanja različitih pokazatelja upotrebe IKT u preduzećima u Srbiji: primena računara i računarskih mreža, upotreba Interneta i mobilnog interneta za poslovne potrebe, posedovanje veb-sajt, primena postupaka E-trgovina, društvenih mreža i klaud (cloud) servisa u preduzećima. Na osnovu izvršenih analiza zaključeno je da je prisutna tendencija rasta primene IKT u poslovanju preduzeća u Srbiji.

Adresa autora zaduženog za korespodenciju: Dušan Regodić

莑=dusanregodic5@gmail.com
Međutim, može se zapaziti da se neki aspekti poslovanja odlikuju značajnom primenom IKT, dok, 
u nekim drugim, upotreba ovih tehnologija još uvek nije zastupljena u značajnijoj meri.

Ključne reči: informaciono-komunikacione tehnologije, Indeks mrežne spremnosti, digitalna ekonomija, Internet, rang zemalja.

\begin{abstract}
Digitalization is rapidly bringing changes and transforms our lives, economy, and society as a whole. New technologies are contributing to the more efficient business, community advancement and, as such, provide the basis for all our private and public sector partnerships to keep up with the current trends of the global market, or participate in what is called the digital economy. The subject of this paper is the application of information and communication technologies (ICT) in the operations of enterprises in Serbia. The paper aims to analyze the applications of ICT by examining various indicators. The starting point is that ICTs are the key factor for increasing economic efficiency, removing barriers, creating new business opportunities for geographical decentralization, and adapting businesses to new business conditions. The latest data from relevant domestic and international institutions were used for the analysis. The first part of the paper describes the current global technological trends and their impact on business operations and ways of measuring countries' readiness to use ICT. The second part of the paper analyzes the trends of different indicators of ICT usage in enterprises in Serbia: implementation of computers and computer networks, use of the Internet and mobile Internet for business purposes owning websites, applying E-commerce, social networking, and cloud services in businesses. Based on the performed analysis, it was concluded that there is a tendency of increasing the use of ICT in the business operations of enterprises in Serbia. However, it can be observed that some aspects of the business are characterized by significant use of ICT, while in others the use of these technologies is not yet represented to a significant extent.
\end{abstract}

Keywords: information and communication technologies, Networked Readiness Index, digital economy, Internet, Country Ranking.

\section{UVOD}

IKT revolucija predstavlja proces koji se realizuje na globalnom nivou i koji uključuje nekoliko aspekata koji su od značajnog značaja uticaj na sve države. Primena informacionih i komunikacionih tehnologija (IKT) „postaje od velike važnosti za većinu aktivnog stanovništva u razvijenim i zemljama u nastajanju "(Baltac, 2011).

Digitalna revolucija je stvorila nove mogućnosti za unapređenje poslovanja, pokrenula dalji rast $i$ razvoj ekonomije. Ova revolucija je omogućila:

- pristup većem broju informacija.

- uvođenje visokih tehnologija u proces poslovanja.

- ostvarivanje konkurentne prednosti.

- stvaranje novih načina poslovanja.

- stvaranje mogućnosti za dalji razvoj i inovacije IKT.

Osnovne komponente digitalne ekonomije čine znanje, internet i tehnologije koje omogućuju upravljanju i razvoju poslovanja između privrednih subjekata, državne uprave i građana. Glavni učesnici digitalne ekonomije su:
Government (država, administracija, uprava), Business (privreda, privredni subjekti) i fizička lica-kupci, potrošači, građani (Customer, Consumer, Citizen).

Informaciono komunikacione tehnologije utiču na unapređenje poslovanja primenom sledećih koncepata:

- Sistemi za upravljanje dokumentacijom.

- Računovodstveni programi.

- Podrška za upravljanje lancima snabdevanja.

- Poslovna inteligencija i izveštavanje o poslovanju preduzeća.

- Elektronska prodaja.

- Elektronsko bankarstvo i

- Internet marketing.

Postoji veći broj definicija IKT infrastrukture. Mogu se izdvojiti sledeće (Vujin, 2012, str. 15):

1. IKT infrastrukturu čine hardver, softver $i$ računarska mreža, koji su potrebni da se razvijaju, testiraju, isporučuju, nadgledaju, kontrolišu ili podržavaju IKT usluge. Termin IKT infrastruktura uključuje sve oblasti informacionih tehnologija, ne uključujući ljude, procese i dokumentaciju. 
2. IKT infrastruktura podržava distribuirano operativno i administrativno računarsko okruženje. U aplikativnom okruženju IT infrastruktura je nevidljiva krajnjim korisnicima, ona obuhvata protokole i računarske mreže povezujući računarske resurse, ali olakšava i tokove podataka.

3. IKT infrastruktura uključuje procesore, softver, baze podataka i računarske centre kao i standarde koji obezbeđuju njihovo zajedničko funkcionisanje [5].

Fizičke komponente IKT infrastrukture su:

- Računarski centri.

- Serveri.

- Računarska mreža.

- Skladištenje podataka.

- Virtualizacija.

- Operativni sistem.

- Uređaji krajnjeg korisnika za pristup računarskim resursima.

$\mathrm{Za}$ programere, IKT infrastruktura predstavlja platformu na kojoj razvijaju i na kojoj se izvršavaju njihove aplikacije. Za administratore računarske mreže, IKT infrastruktura je skup mrežnih uređaja i međusobnih veza. Za sistem administratore, IKT infrastrukturu čine uređaji kojima oni upravljaju, a za arhitekte sistema IKT infrastruktura predstavlja osnovu za izgradnju poslovnih sistema i servisa (A Longitudinal Analysis of the Impact of the Indicators in the Networked Readiness Index, 2019)].

IKT infrastruktura može funkcionisati i bez implementiranih kvalitativnih komponenti, ali se prava upotrebljivost infrastrukture može realizovati tek kroz realizaciju i upravljanje sledećim komponentama:

- Bezbednost.

- Dostupnost.

- Efikasnost.

- Administracija sistema.

Internet je tehnologija koja je u kratkom vremenu doživela intenzivnu primenu u poslovanju. Internet i informaciono-komunikacione tehnologije utiču u većoj meri na razvoj ekonomije od drugih faktora političkog, ekonomskog ili društvenog karaktera. Internet kao infrastrukturna i komunikaciona tehnologija utiče na razvoj i unapređenje poslovanja pružajući podršku za:
- Razvoj sistema koji omogućavaju obradu velike količine podataka i dobijanje rezultata u kratkom vremenu.

- Telekomunikacije, razvojem tehnologije za računarske mreže velike brzine, bežičnih sistema i satelita, koji omogućavaju direktnu vezu između računara i brz prenos podataka širom sveta.

- Inteligentne programske sisteme za upravljanje računarskim mrežama, hardverom i softverom.

Infrastruktura elektronskog poslovanja je skup platformi, mreža, proizvoda, aplikacija, podataka i poslovnih pravila namenjenih upravljanju internim i eksternim poslovnim procesima. Infrastruktura se može shvatiti i kao skup tehnologija i kao skup platformi i servisa.

Digitalna ekonomija je jedan od najznačajnijih faktora ekonomskog rasta u svetu. Trenutno raste 5 do 7 puta brže od ostalih ekonomskih sektora. Prilike za rast $\mathrm{i}$ inovacije često imaju digitalni predznak u skoro svim sektorima ekonomije, od automobilske industrije, preko energetike (pametne mreže), javne administracije (eUprava), pa sve do opštih usluga (e-Zdravlje). Vođenje bilo kakvog poslovanja, od startapa do velikih korporacija, zahteva dostupnost vrhunskih digitalnih usluga i infrastrukture. Republika Srbija prepoznaje ekonomski potencijal koji bi imalo stvaranje jedinstvenog digitalnog tržišta, u ovom trenutku treba jasno definisati prioritete i ciljeve, odrediti viziju digitalne ekonomije i uspostaviti pravni okvir za njen dalji razvoj.

Primena informaciono komunikacionih tehnologija (IKT) u globalnom svetskom okruženju je u stalnom porastu, slika 1. $4,000,000,000$

2016. $-46,1 \%-3.424 .971 .237$

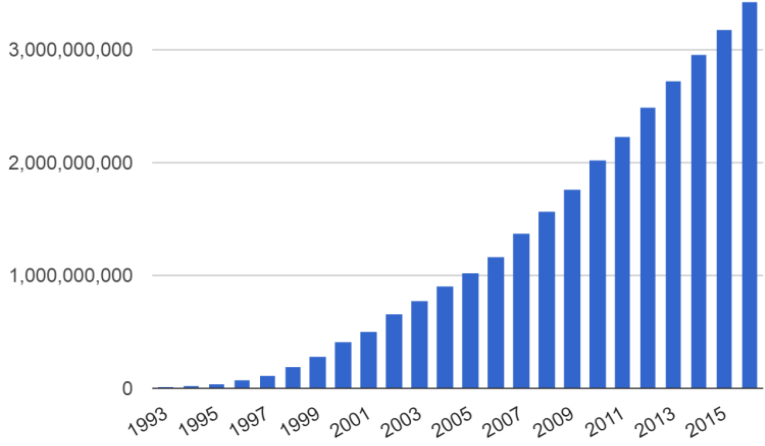

Slika 1. Primena Interneta u svetu do 2016. godine.

Izvor:(Republički zavod za statistiku, 2016) 
Skoro polovina svetske populacije je povezana na internet. Prognoze su bile da će od 7.75 milijardi stanovnika u svetu u 2020.godini Internet koristiti 4.54 milijardi ili 59\% ukupnog stanovništva. To je za $7 \%$ više nego u 2019.godini (52\% stanovništva).

Na slici 2. (Republički zavod za statistiku, 2019) prikazan je procenat korisnika Interneta prema radnom status u Srbiji od 2010. godine do 2019.godine.

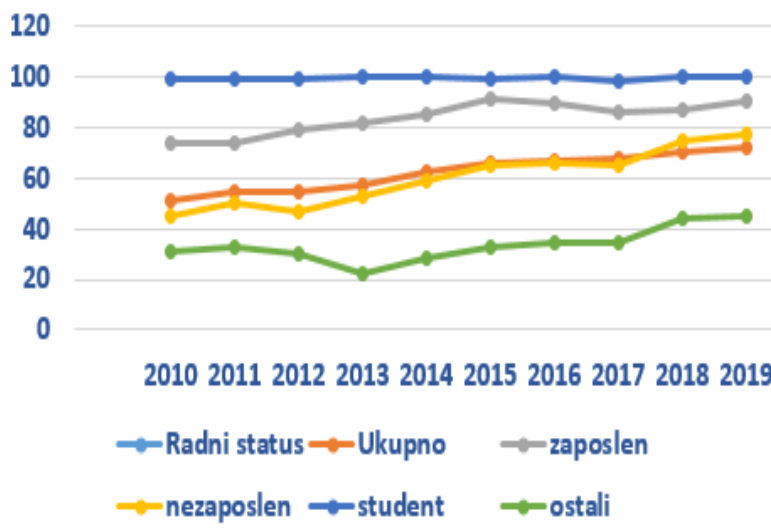

Slika 2. Korisnici računara u Srbiji prema radnom statusu.

$\mathrm{Na}$ slici 3. (Soumitra D., \& Lanvin B., 2020) prikazana je Svetska prognoza za e-trgovinu. Prema očekivanjima do 2021. globalna e-prodaja će dostići 4,4 milijardi USD.

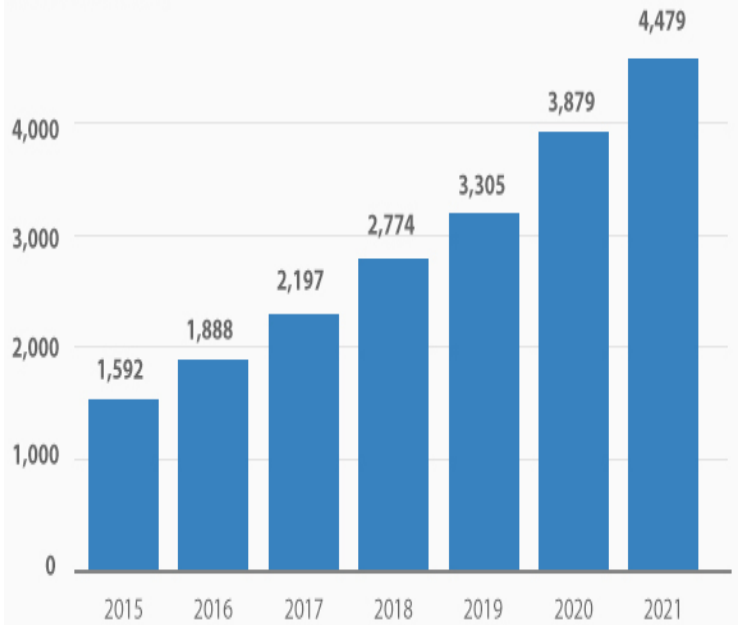

Slika 3. Svetska prognoza za e-trgovinu od 2015. godine do 2021.godine.

Primena mobilnog web internet prometa u svetu u 2018.godini prikazana je na slici 4. (Republički zavod za statistiku, 2019). Od 83\% ukupnog internet prometa Kenije se ostvaruje preko mobilnih uređaja.

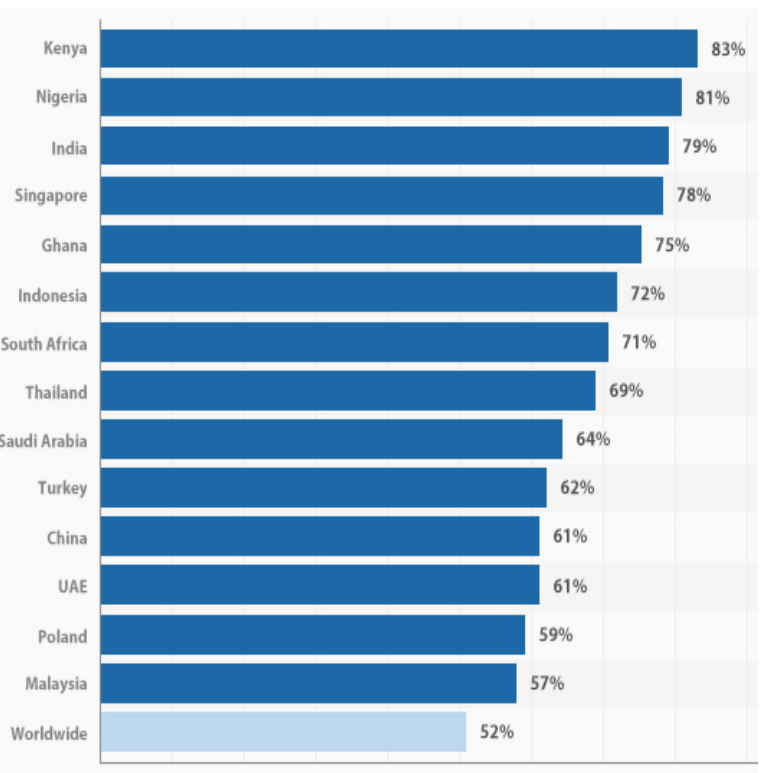

Slika 4. Postotak mobilnog web internet prometa u 2018.god.

Proboj tableta je polako rastao u zadnjih nekoliko godina. Do 2020. tablete će koristiti $35 \%$ svih korisnika interneta, slika 5 (Soumitra D., \& Lanvin B., 2020).

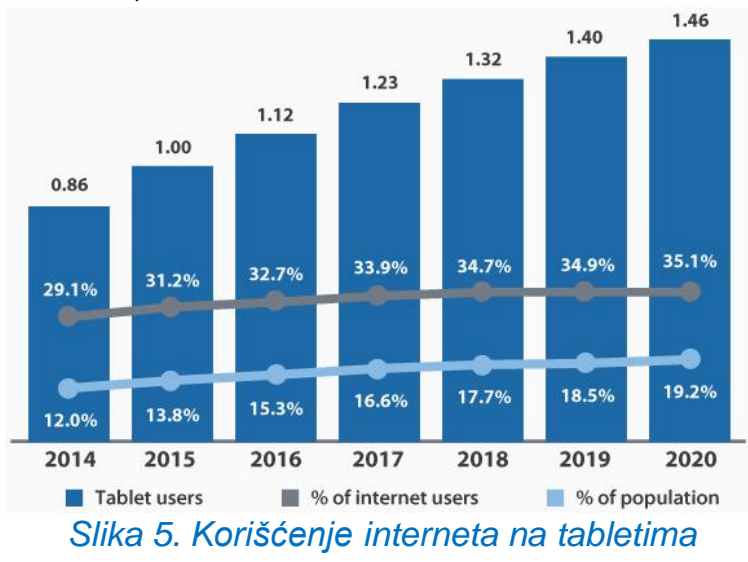

Na slici 6 (Soumitra D., Lanvin B., 2020) su prikazani vodeće zemlje u globalnoj potrošnji u etrgovini.

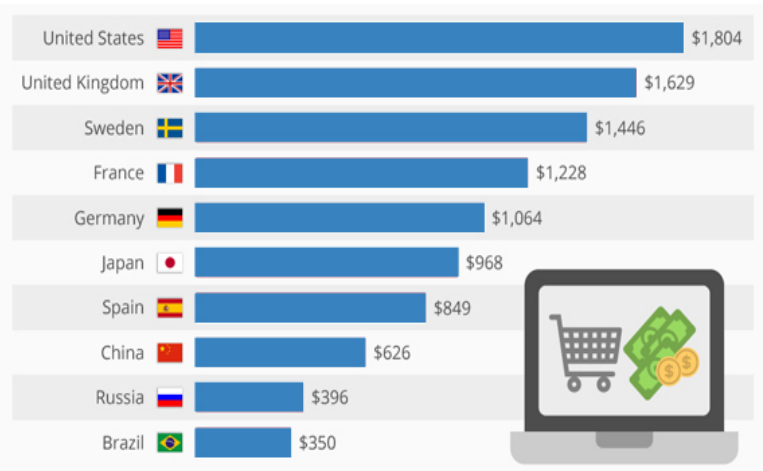

Slika 6. Vodeći globalni potrošači u etrgovinama. 
U proseku, Google obrađuje više od 40.000 pretraživanja svake sekunde $(3,5$ milijardi pretraga dnevno). U 2005. godini čovečanstvo je kreiralo 150 eksabajta podataka ( 1 eksabajt $=1$ milijarda gigabajta), a u 2016. godini preko 3500 eksabajta.

Privredni subjekti koji ostanu digitalno nepovezani biće u relativno bliskoj budućnosti isključeni iz globalnog tržišta. Ogroman potencijal digitalne ekonomije je još uvek nedovoljno iskorišćen, naročito u Republici Srbiji.

Primena IKT omogućuje velike uštede $u$ poslovanju, poboljšava kvalitet proizvoda i usluga koje se pružaju, skraćuje vreme potrebno za izvršenje posla i smanjuje administriranje. IKT se već nekoliko decenija unazad koriste za transformaciju internih $i$ eksternih poslovnih procesa. Upotreba IKT je tradicionalno bila vezana za interne poslovne operacije i procese, tj. odnose između internih poslovnih grupa (menadžeri, vlasnici, radnici). Kasnije je počela da se koristi i za unapređenje poslovnih odnosa i procesa između preduzeća i spoljnih poslovnih subjekata (kupci, dobavljači, skladišta, maloprodaja, banke i drugi).

Imajući u vidu ove globalne trendove cilj ovog rada je da pokaže koliko i kako preduzeća u Srbiji primenjuju informaciono-komunikacione tehnologije u svom poslovanju. Za komparativnu analizu korišćeni su najnoviji podaci relevantnih domaćih i međunarodnih institucija.

\section{PREGLED LITERATURE}

Svetski ekonomski forum od 2001. godine, objavljuje "Izveštaj o globalnoj informacionoj tehnologiji (GITR)“, razvija indeks nazvan Indeksom mrežne spremnosti (NRI) za oko 140 zemalja. Uticaj IKT na poslovanja i podizanje efikasnosti i konkurentnosti preduzeća razmatraju (Real, Leal, \& Roldan, 2006). Uticaj IKT karakteristika, zakona i sigurne komunikacije na mrežnu spremnost različitih zemalja ocenjuju (lunis, Ngafeeson, \& Koong, 2014). Primena Rogerove difuzijske teorije inovacija razvijen 1962. godine, na GITR podatke testiran od 2012. do 2015 (Degerli, 2015).

Alternativni okvir za ponderisanje zasnovan je na metodologiji izračunavanja NRI na daljinu NRI (Milenković, Brajović, Milenković, Vukmirović, \& Jeremić, 2015). Indeks mrežne spremnosti ima jasnu politiku i procedure vođenja (Baller, Dutta, \& Lanvin, 2016).

Analizu i kvalitativne ocene dostignutog nivoa $u$ primeni IKT i rangiranje država bave se i Ujedinjene nacije (UN), koje rangiraju zemlje na osnovu vrednosti IDI indeksa (ICT Development Index-IDI), kompozitnog indeksa. Na osnovu IDI indeksa za 2017, najbolje rangirane članice EU su Danska, Velika Britanija i Holandija (United Nations, 2018). J. Soldić Aleksić i R. Stankić (2015) predstavili su Networked Readiness Index (NRI), kompozitni indeks koji izračunava i objavljuje Svetski ekonomski forum (World Economic Forum). Danas struktura NRI je kompleksna, jer se sastoji od 62 indikatora primene IKT u ekonomiji i društvu. Što se tiče podele evropskih zemalja po uspešnosti u primeni IKT na osnovu ovog indeksa, ona je regionalna, pri čemu se ocenjuje da su zemlje Južne, Centralne i Istočne Evrope u zaostatku za zemljama Severne i Srednje Evrope.

Primenu IKT u evropskim zemljama analizirali su u 2018.godini: J. Becker, A. Becker, P. Sulikowski i T. Zdziebko. Oni rangiraju zemlje Centralne Evrope, članice EU (Austrija, Republika Češka, Nemačka, Mađarska, Slovačka i Slovenija) prema primeni IKT u preduzećima, koristeći Analytic Network Process (ANP). Dokazano je da su u ovoj grupi zemalja Slovenija i Austrija lideri u pogledu primene IKT u preduzećima za 2017. (Zečević, A., \& Radović Stojanović, J., 2018) analiziraju primenu IKT u Sloveniji, Hrvatskoj, Republici Srbiji, Bosni i Hercegovini, Makedoniji i Crnoj Gori.

Uticaj IKT na privredni rast i razvoj razmatraju (Stankic, Jovanovic Gavrilovic \& Soldic Aleksic, 2018), dok uticaj na ekonomiju i društvo u celini razmatraju (Roztocki, Soja, \& Weistroffer, 2019).

Može se zaključiti da se naučni radovi prvenstveno bave, efektima IKT na poslovanje i rad preduzeća, dok su implementacija IKT i njihova primena u preduzećima nedovoljno obrađeni, o čemu svedoči mali broj radova.

\section{DIGITALNE TEHNOLOGIJE U SAVREMENOM SVETU EKONOMIJE}

Tehnologija može imati važan pozitivan uticaj na nacionalne ekonomije i na njihovu sposobnost da 
dostignu ciljeve održivog razvoja, ali to se neće postići ako ne budu u stanju da uspostave efikasne mehanizme upravljanja koji će integrisati tehnologiju sa tri ključne interesne grupe: pojedinci, preduzeća i vlade. Tehnologija i uticaj IKT su ključni pokretači na osnovu kojih se razlikuju regioni. Digitalna ekonomija raste sedam puta brže od ostalih grana privrede. Ovom rastu najviše doprinosi rasprostranjenost interneta (Soumitra D., Lanvin B., 2020). Danas široko pojasne mreže interneta velikih brzina imaju važan uticaj na uvođenje inovativnih usluga kao što su: e-zdravstvo, poslovanje u lancu snabdevanja, pametni gradovi i proizvodnja zasnovana na podacima.

Koncept digitalne ekonomije se $u$ poslednje vreme razvija zbog višestruke i dinamičke prirode i transformacija digitalnih tehnologija. Digitalna ekonomija je značajna jer ubrzava globalni ekonomski razvoj, povećava produktivnost postojećih industrija, neguje i podstiče nova tržišta $i$ industrije, postiže sveobuhvatnost $i$ održivi rast, kao i zaštitu životne sredine (Milenkovic, M. J., Brajovic, B., Milenkovic, D., Vukmirovic, D., \& Jeremic, V., 2015 ). Evropska unija (EU) smatra da je digitalna ekonomija najvažniji pokretač inovacija, konkurentnosti i rasta u svetu (European Commission, 2018). U Akcionom planu EU za preduzetništvo 2020 naglašeno je da potencijal digitalnih tehnologija podstiče konkurentnost, preduzetništvo i inovativnost.

Svetska privreda se ubrzano digitalizuje. Informacione i komunikacione tehnologije (IKT) više nisu poseban sektor, već osnov svih modernih inovativnih privrednih subjekata. Internet i digitalne tehnologije menjaju način života i rada pojedinaca, ali i privrednih subjekata i društva u celini, jer sve više prodiru u sve sektore privrede i društva. Ove promene se dešavaju brzo i donose brojne mogućnosti za inovacije, rast $i$ zapošljavanje. Nove digitalne tehnologije, kao što su cloud computing, mobilni web servisi, pametne i društvene mreže, radikalno menjaju poslovanje, preoblikujući prirodu poslovanja i poslovni pejzaž privrednih subjekata $\mathrm{i}$ njihovih lidera. Ove trendove omogućavaju tehnološke inovacije, koje podstiču inovacije poslovnih modela, poslovno povezivanje i prenos znanja i pristupe međunarodnim tržištima (Soumitra D., \& Lanvin B., 2020).
Evropska unija je 2010. godine pokrenula desetogodišnju strategiju za rast i zapošljavanje, kojom treba da se obezbede uslovi za pametan i održiv rast. Uključeno je pet glavnih ciljeva za EU do kraja 2020. godine: zapošljavanje, istraživanje i razvoj, klimatske promene/energija, obrazovanje, socijalna uključenost $i$ smanjenje siromaštva (Soumitra D., Lanvin B., 2020). Strategija jedinstvenog digitalnog tržišta EU se temelji na tri osnovna stuba:

1. Boljem pristupu potrošača i privrednih subjekata robi i uslugama preko interneta $u$ celoj Evropi.

2. Stvaranjem odgovarajućih uslova za razvoj digitalnih mreža i usluga i

3. Iskorišćavanjem punog potencijala rasta evropske digitalne ekonomije.

Nove digitalne mogućnosti stvaraju nove poslovne mogućnosti. U situaciji kada je u EU nezaposlenost mladih porasla na preko $20 \%$ (i do preko $55 \%$ u Španiji i Grčkoj), izgledi rasta za zapošljavanje koje daje digitalna ekonomija su obećavajući. Digitalna ekonomija sada čini $8 \%$ društvenog bruto proizvoda u zemljama G20 (grupa od 20 velikih ekonomija obuhvata sledeće zemlje: Argentina, Australija, Brazil, Kanada, Kina, EU, Francuska, Nemačka, Indija, Indonezija, Italija, Japan, Meksiko, Rusija, Saudijska Arabija, Južna Afrika, Južna Koreja, Turska, Velika Britanija, i SAD), i omogućava otvaranje novih radnih mesta.

$\mathrm{Za}$ merenje razvijenosti digitalne ekonomije $\mathrm{u}$ jednoj zemlji koristan je i Indeks mrežne spremnosti (Networked Readiness Index-NRI).

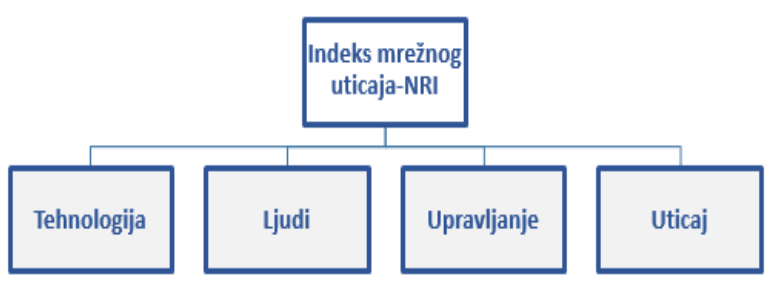

Slika 7. Način praćenja NRI

Na slici 7. prikazano je praćenje NRI: tehnologije (pristup novim tehnologijama, sadržaj tehnologija, budući razvoj), primena tehnologija od strane ljudi (pojedinci, preduzeća, vlade), način upravljanja digitalnom ekonomijom (poverenje i sigurnost, mere države i uključenost), uticaj digitalne ekonomije na poboljšanje rasta i blagostanja $u$ društvu i ekonomiji (na ekonomiju, kvalitet života i održivi budući razvoj društva). 
NRI je mera spremnosti zemlje da iskoristi mogućnosti koje nude informacione i komunikacione tehnologije.

Indeks je evoluirao tokom vremena i trenutno se izračunava na osnovu četiri glavne komponente (podindeksa), 12 potkategorija (stubova) i 62 pojedinačna indikatora, koji mere parametre okruženja za IKT u datoj zemlji ili zajednici i spremnost članova zajednice (pojedinaca, preduzeća i javne uprave) za primenu IKT.

Srbija je na 52 mestu sa NRI koji iznosi 53,65 i to: tehnologije-50,54; ljudi-46,53; način upravljanja61,49 i uticaj-56.3.

Prvih deset zemalja u NRI za 2019. godinu je prikazan u tabeli 1 . Na vrhu rang liste dominiraju evropske zemlje, a evropska regija je zauzela 8 od prvih 10 mesta. Sjedinjene Države su na 8. mestu u svetu.

Tabela 1. Rang lista prema NRI

\begin{tabular}{|l|c|c|}
\hline \multicolumn{1}{|c|}{ Zemlja } & $\begin{array}{c}\text { Indeks mrežne } \\
\text { spremnosti-NRI }\end{array}$ & Rang \\
\hline Švedska & 82,65 & 1 \\
\hline Singapur & 82,13 & 2 \\
\hline Holandija & 81,78 & 3 \\
\hline Norveška & 81,30 & 4 \\
\hline Švajcarska & 81,08 & 5 \\
\hline Danska & 81,08 & 6 \\
\hline Finska & 80,34 & 7 \\
\hline SAD & 80,32 & 8 \\
\hline Nemačka & 78,23 & 9 \\
\hline Velika Britanija & 77,73 & 10 \\
\hline
\end{tabular}

Na slici 8. dat je grafički prikaz procenta NRI u 2019.god. u odnosu na 2016.god.

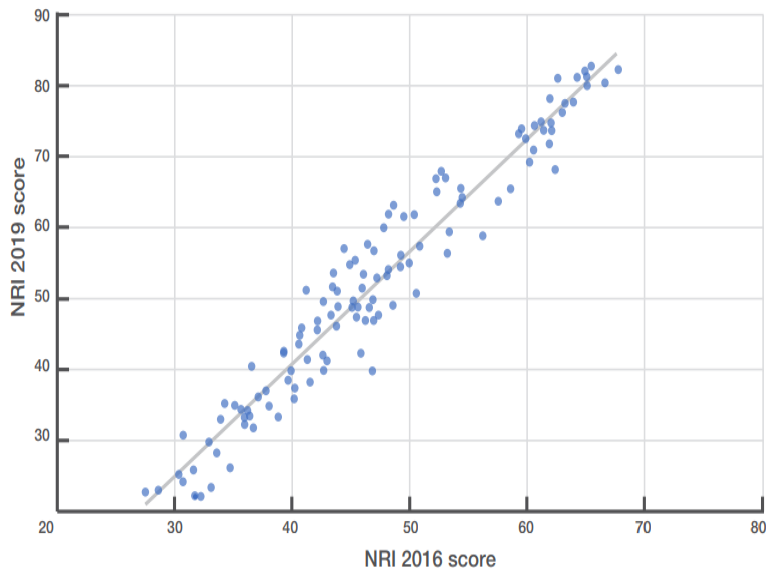

Slika 8. Grafički prikaz procenta NRI u 2019.god. u odnosu na 2016. god. $R^{2}=0,94$.

(Soumitra D., \& Lanvin B., 2020).
U tabeli 2. dat je uporedni pristup NRI Srbije i Hrvatske od 2010.godine do 2019.godine (Soumitra D., \& Lanvin B., 2020).

Tabela 2. Uporedni pristup NRI Srbije i Hrvatske

\begin{tabular}{|c|c|c|}
\hline \multirow{2}{*}{$\begin{array}{c}\text { NRI po godinama } \\
\text { (broj posmatranih } \\
\text { zemalja) }\end{array}$} & \multicolumn{2}{|c|}{ Pozicija na listi } \\
\cline { 2 - 3 } & Srbija & Hrvatska \\
\hline 2010.(138) & 94 & 51 \\
\hline $2011 .(138)$ & 93 & 54 \\
\hline $2012 .(142)$ & 85 & 45 \\
\hline 2013.(144) & 87 & 45 \\
\hline 2014.(148) & 80 & 46 \\
\hline $2015 .(143)$ & 77 & 54 \\
\hline $2016 .(139)$ & 75 & 54 \\
\hline $2019 .(121)$ & 52 & 44 \\
\hline
\end{tabular}

Od 2001. godine Svetski ekonomski forum (World Economic Forum) u saradnji sa INSEAD - The Business School for the World (https://www.insead.edu) i sa Cornell University (http://www.johnson.cornell.edu/) u svrhe merenja globalne IKT revolucije objavljuje Izveštaj za globalne informacione tehnologije, koristeći Indeks mrežne spremnosti. Indeks je vremenom evoluirao i trenutno procenjuje stanje mrežne spremnosti koristeći 62 pojedinačna indikatora. U Izveštaju iz 2019. godine je obuhvaćeno 121 ekonomija i indeks omogućuje identifikaciju prioritetnih oblasti za potpunije korišćenje IKT za društveno ekonomski razvoj. Prema ovom istraživanju Srbija je na 52 mestu sa ocenom indeksa mrežne spremnosti 53,65 , od 121 posmatranih ekonomija sveta. Ocena prvih na listi Švedske (82.65), Singapura (82.13) i Holandije (81.78) (Soumitra D., \& Lanvin B., 2020).

U tabeli 3. i 4. (Republički zavod za statistiku, 2019) prikazani podaci ukazuju na stepen upotrebe IKT u domaćinstvima i privrednim subjektima u Republici Srbiji. Prema metodologiji Evrostata, u navedenoj tabeli su izneta istraživanja sprovedena u 2019. godini Republičkog zavoda za statistiku, za privredne subjekte sa 10 i više zaposlenih. Anketa za domaćinstva sprovedena je na dvofaznom uzorku, stratifikovanom po kriterijumu urbanosti. Uzorak je alociran na područja centralne Srbije (bez Beograda), AP Vojvodine i Beograda, proporcionalno broju domaćinstava. Obim uzorka iznosi 2.800 domaćinstava i 2.800 pojedinaca. Ispitivanje je sprovedeno telefonskim putem, a 
bilo je dozvoljeno i posredno anketiranje (davanje odgovora umesto odsutnog lica). Anketa za preduzeća sprovedena je na uzorku stratifikovanom po veličini i delatnosti, telefonom.
Istraživanje je sprovođeno od 15. aprila do 30 . aprila 2019. Veličina uzorka: 1.597 preduzeća (Republički zavod za statistiku, 2019). Tip uzorka: Stratifikovan uzorak.

Tabela 3. Prikaz zastupljenosti (\%) domaćinstava koji poseduju računar, Internet i širokopojasnu konekciju od 2006. - 2018.godine.

\begin{tabular}{|c|c|c|c|c|c|c|c|c|c|c|c|c|c|}
\hline & \multicolumn{13}{|c|}{ REPUBLIKA SRBIJA ${ }^{1}$} \\
\hline & 2006 & 2007 & 2008 & 2009 & 2010 & 2011 & 2012 & 2013 & 2014 & 2015 & 2016 & 2017 & 2018 \\
\hline \multicolumn{14}{|c|}{ Domaćinstva koja poseduju računar, prema tipu naselja } \\
\hline Ukupno & 26,5 & 34,0 & 40,8 & 46,8 & 50,4 & 52,1 & 55,2 & 59,9 & 63,2 & 64,4 & 65,8 & 68,1 & 72,1 \\
\hline Gradska naselja & 31,6 & 42,7 & 47,5 & 56,0 & 58,7 & 60,8 & 63,0 & 66,3 & 68,9 & 71,1 & 73,3 & 73,5 & 78,2 \\
\hline Ostala naselja & 18,8 & 21,6 & 31,2 & 33,6 & 38,3 & 39,7 & 43,9 & 50,9 & 53,7 & 53,9 & 54,0 & 60,7 & 61,8 \\
\hline \multicolumn{14}{|c|}{ Domaćinstva koja poseduju Internet priključak, prema tipu naselja } \\
\hline Ukupno & 18,5 & 26,3 & 33,2 & 36,7 & 39,0 & 41,2 & 47,5 & 55,8 & 62,8 & 63,8 & 64,7 & 68,0 & 72,9 \\
\hline Gradska naselja & 22,5 & 35,0 & 41,2 & 46,9 & 49,3 & 51,0 & 57,5 & 63,8 & 67,8 & 70,1 & 72,5 & 72,9 & 78,3 \\
\hline Ostala naselja & 12,5 & 13,7 & 21,7 & 22,0 & 24,1 & 27,2 & 33,2 & 42,5 & 51,1 & 53,2 & 53,8 & 59,8 & 63,9 \\
\hline \multicolumn{14}{|c|}{ Domaćinstva koja poseduju broadband Internet konekciju, prema tipu naselja } \\
\hline Ukupno & - & 7,3 & 15,5 & 22,9 & 27,6 & 31,0 & 38,0 & 43,4 & 55,1 & - & 57,8 & 61,9 & 72,5 \\
\hline Gradska naselja & - & - & 21,6 & 33,7 & 38,9 & 41,2 & 48,3 & 52,4 & 63,3 & - & 66,8 & 67,5 & 77,9 \\
\hline Ostala naselja & - & - & 6,8 & 7,4 & 11,4 & 16,4 & 23,1 & 28,5 & 41,5 & - & 44,0 & 52,3 & 63,5 \\
\hline
\end{tabular}

Tabela 4. Prikaz zastupljenosti (\%) preduzeća koji poseduju računar, koriste Internet i imaju web sajt od 2006.- 2018.godine.

\begin{tabular}{|c|c|c|c|c|c|c|c|c|c|c|c|c|c|}
\hline & \multicolumn{13}{|c|}{ REPUBLIKA SRBIJA ${ }^{1}$} \\
\hline & 2006 & 2007 & 2008 & 2009 & 2010 & 2011 & 2012 & 2013 & 2014 & 2015 & 2016 & 2017 & 2018 \\
\hline \multicolumn{14}{|c|}{ Preduzeća koja koriste računar u svom poslovanju, prema veličini preduzeća } \\
\hline UKUPNO & 97,3 & 97,7 & 97,7 & 97,8 & 97,8 & 98,1 & 98,7 & 100,0 & 100,0 & 100,0 & 99,8 & 100,0 & 99,3 \\
\hline Mala (10-49 zaposlenih) & 96,7 & 96,9 & 96,9 & 97,0 & 97,1 & 98,0 & 98,3 & 100,0 & 100,0 & 100,0 & 99,6 & 100,0 & 99,4 \\
\hline Srednja (50-249 zaposlenih) & 98,7 & 98,9 & 98,9 & 100,0 & 100,0 & 100,0 & 99,8 & 100,0 & 100,0 & 100,0 & 100,0 & 100,0 & 99,0 \\
\hline Velika (250 i više zaposlenih) & 100,0 & 100,0 & 100,0 & 100,0 & 100,0 & 100,0 & 100,0 & 100,0 & 100,0 & 100,0 & 100,0 & 100,0 & 100,0 \\
\hline \multicolumn{14}{|c|}{ Preduzeća koja koriste Internet u svom poslovanju, prema veličini preduzeća } \\
\hline UKUPNO & 90,2 & 90,6 & 91,5 & 94,5 & 96,8 & 97,2 & 97,7 & 99,6 & 100,0 & 99,1 & 99,8 & 99,7 & 99,8 \\
\hline Mala (10-49 zaposlenih) & 89,7 & 89,9 & 89,9 & 93,4 & 96,3 & 96,3 & 97,3 & 99,5 & 100,0 & 98,9 & 99,8 & 99,7 & 99,7 \\
\hline Srednja (50-249 zaposlenih) & 90,9 & 91,0 & 96,1 & 97,7 & 98,2 & 99,9 & 99,0 & 100,0 & 100,0 & 100,0 & 99,9 & 99,6 & 100,0 \\
\hline Velika (250 i više zaposlenih) & 94,1 & 94,5 & 96,8 & 100,0 & 99,3 & 100,0 & 100,0 & 100,0 & 100,0 & 100,0 & 100,0 & 100,0 & 100,0 \\
\hline \multicolumn{14}{|c|}{ Preduzeća koja imaju veb sajt, prema veličini preduzeća } \\
\hline UKUPNO & 52,9 & 61,8 & 68,9 & 67,0 & 67,5 & 67,6 & 73,8 & 73,8 & 74,0 & 75,2 & 80,8 & 80,4 & 82,6 \\
\hline Mala (10-49 zaposlenih) & 49,6 & 59,4 & 65,7 & 62,5 & 62,8 & 63,2 & 70,3 & 69,1 & 71,0 & 71,2 & 77,9 & 76,9 & 80,1 \\
\hline Srednja (50-249 zaposlenih) & 59,9 & 63,7 & 76,1 & 79,8 & 82,1 & 79,3 & 84,1 & 87,7 & 81,5 & 88,0 & 89,8 & 92,1 & 90,4 \\
\hline Velika (250 i više zaposlenih) & 75,2 & 82,4 & 83,9 & 81,0 & 86,7 & 89,0 & 89,3 & 87,0 & 93,7 & 92,9 & 93,9 & 93,6 & 94,8 \\
\hline
\end{tabular}

\subsection{Uzorak istraživanja}

Istraživanje o upotrebi informacionokomunikacionih tehnologija u preduzećima sprovedeno je na reprezentativnom uzorku od 1597 preduzeća (mala, srednja i velika) na teritoriji Republike Srbije (Republički zavod za statistiku, 2019). Stopa odgovora je 85,1\% (1359 preduzeća) i to:

- Prerađivačka industrija - 523.

- Snabdevanje električnom energijom, gasom, parom i vodom; Upravljanje otpadnim vodama -68 . 
- Građevinarstvo - 80.

- Trgovina na veliko i malo - 198.

- Saobraćaj i skladištenje - 74.

- Usluge smeštaja i ishrane - 92.

- Informisanje i komunikacije - 113.

- Poslovanje nekretninama; Stručne, naučne i tehničke delatnosti - 109.

- Administrativne i pomoćne uslužne delatnosti; Popravke kompjutera - 102.

Domen istraživanja: Teritorija Republike Srbije (bez AP Kosovo i Metohija).

\subsection{Rezultati istraživanja}

\subsubsection{Primena računara i računarskih mreža u preduzećima}

Rezultati istraživanja pokazuju da $100 \%$ preduzeća u 2019. godini na teritoriji Republike Srbije koristi računar u svom poslovanju, slika 9.

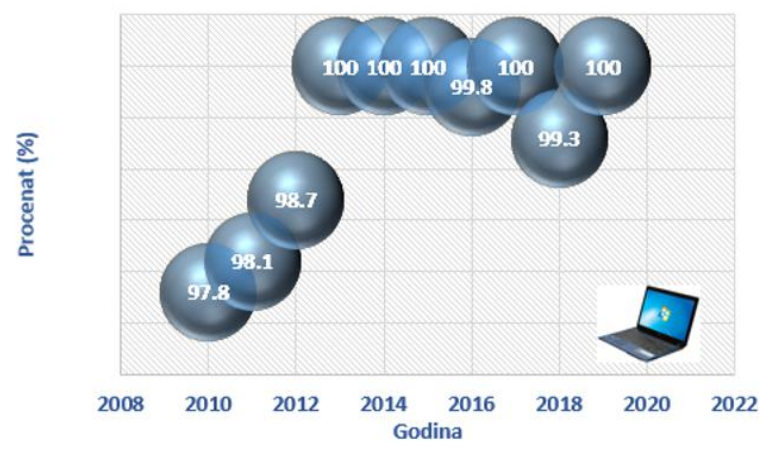

Slika 9. Upotreba računara u poslovanju preduzeća (\%).

U $30,5 \%$ preduzeća od 1 do $24 \%$ zaposlenih lica koristi računar najmanje jedanput nedeljno, dok u $37,7 \%$ preduzeća od 75 do $100 \%$ zaposlenih koriste računar najmanje jedanput nedeljno.

Procenat (\%)

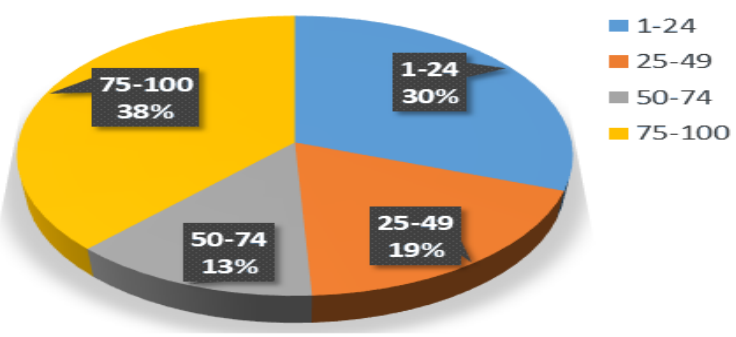

Slika 10. Učešću zaposlenih lica u poslovanju preduzeća koja koriste računar najmanje jedanput nedeljno (\%).

$\mathrm{Na}$ osnovu istraživanja došlo se do zaključka da 20,9\% preduzeća zapošljava IKT stručnjake. IKT stručnjake zapošljava $77,9 \%$ velikih preduzeća, dok je taj procenat kod malih preduzeća 13,4\%.

\subsubsection{Primena Interneta u preduzećima}

U Republici Srbiji, 99,8\% preduzeća ima internet priključak.

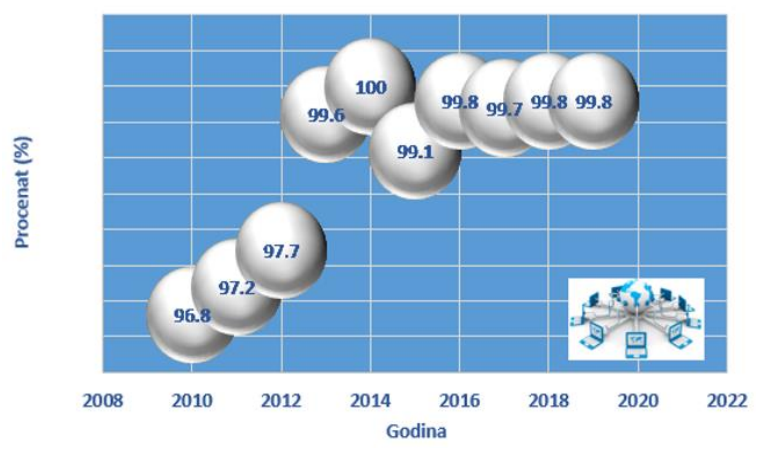

Slika 11. Mogućnost preduzeća da pristupe Internetu (\%)

U $33,4 \%$ preduzeća od 1 do $24 \%$ zaposlenih lica koristi internet najmanje jedanput nedeljno, dok $u$ $32,4 \%$ preduzeća od 75 do $100 \%$ zaposlenih koriste internet najmanje jedanput nedeljno.

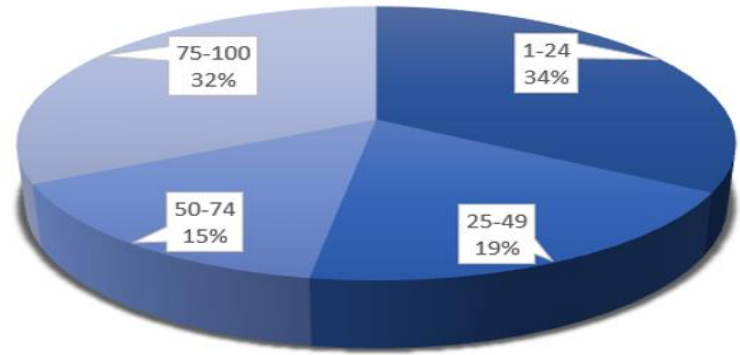

Slika 12. Pregled preduzeća prema učešću zaposlenih lica koja koriste internet najmanje jedanput nedeljno (\%).

$U$ vezi s načinom pristupanja internetu (tipovi konekcije), preduzećima je bilo omogućeno da odaberu nekoliko ponuđenih odgovora.

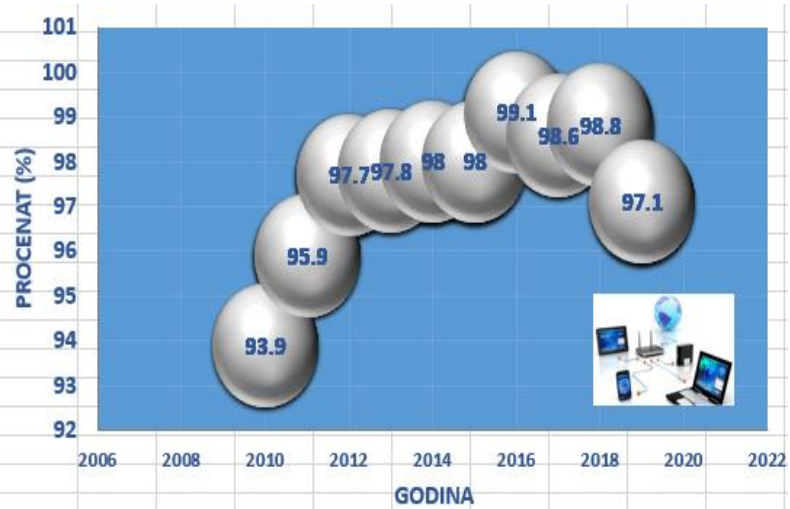

Slika 13. Širokopojasna (broadband) internet konekcija u preduzećima (\%). 
Na osnovu dobijenih rezultata, od ukupnog broja preduzeća koja poseduju internet priključak, širokopojasnu (broadband) internet konekciju ima $97,1 \%$ preduzeća.

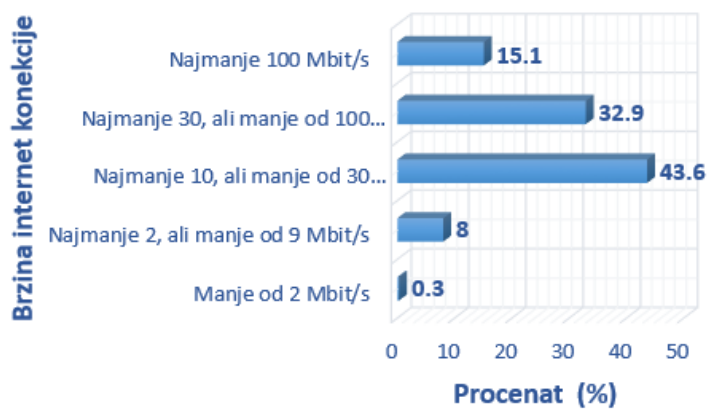

Slika 14. Prikaz maksimalna brzina internet konekcije u preduzećima (\%).

\subsubsection{Primena mobilnog interneta za poslovne potrebe}

Na teritoriji Republike Srbije $79,1 \%$ preduzeća koristi mobilnu internet konekciju upotrebom prenosivih uređaja (smartfon, laptop, tablet...).

Analiza preduzeća prema veličini pokazuje nam da mobilnu internet konekciju upotrebom prenosivih uređaja najviše koriste velika preduzeća $(90,1 \%)$.

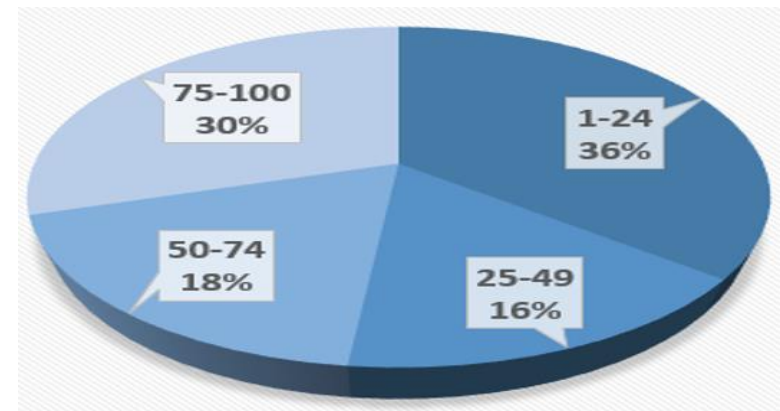

Slika 15. Učešću zaposlenih lica koja koriste prenosive uređaje za poslovne potrebe $u$ preduzećima (\%).

U $35,8 \%$ preduzeća od 1 do $24 \%$ zaposlenih lica koristi prenosive uređaje za poslovne potrebe, dok u $29,8 \%$ preduzeća od 75 do $100 \%$ zaposlenih koriste prenosive uređaje za poslovne potrebe.

\subsubsection{Posedovanje Veb-sajt u preduzećima}

Veb-sajt poseduje $83,6 \%$ preduzeća, što čini povećanje od $1,0 \%$ u odnosu na 2018. i povećanje od 3,2\% u odnosu na 2017. godinu. Kada pogledamo strukturu preduzeća prema veličini, dobijamo sledeće rezultate: $93,1 \%$ velikih preduzeća poseduje veb-sajt; $93,7 \%$ srednjih preduzeća poseduje veb-sajt; $80,5 \%$ malih preduzeća poseduje veb-sajt. $83,6 \%$ preduzeća poseduje veb-sajt Razlike postoje i u zavisnosti od teritorijalne celine. U Beogradu, veb-sajt poseduje $84,0 \%$ preduzeća, u Vojvodini $91,0 \%$, u regionu Šumadije i Zapadne Srbije $78,9 \%$ i u Regionu Južne i Istočne Srbije $75,4 \%$ preduzeća.

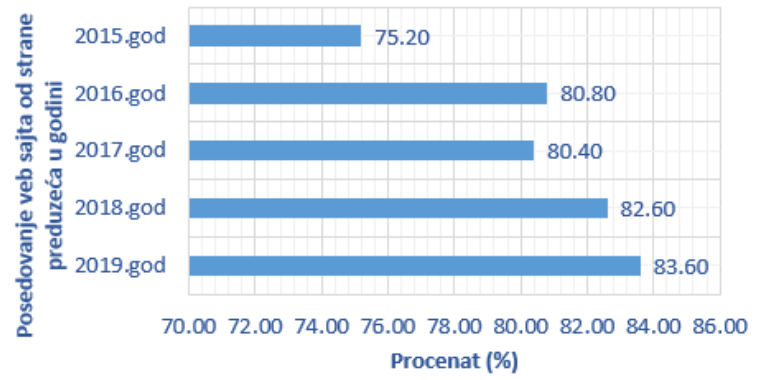

Slika 16. Posedovanje veb sajta od strane preduzeća (\%).

Posedovanje veb-sajta u preduzećima, prema delatnosti:

- Informisanje i komunikacije $(98,1 \%)$.

- Administrativne i pomoćne uslužne delatnosti; Popravke kompjutera $(85,3 \%)$.

- Poslovanje nekretninama; Stručne, naučne i tehničke delatnosti $(92,3 \%)$.

- Prerađivačka industrija $(86,4 \%)$.

- Usluge smeštaja i ishrane $(90,5 \%)$.

- Trgovina na veliko i malo $(79,0 \%)$.

- Građevinarstvo (77,1\%).

- Snabdevanje električnom energijom, gasom, parom i vodom; Upravljanje otpadnim vodama $(78,3 \%)$.

- Saobraćaj i skladištenje (74,5\%).

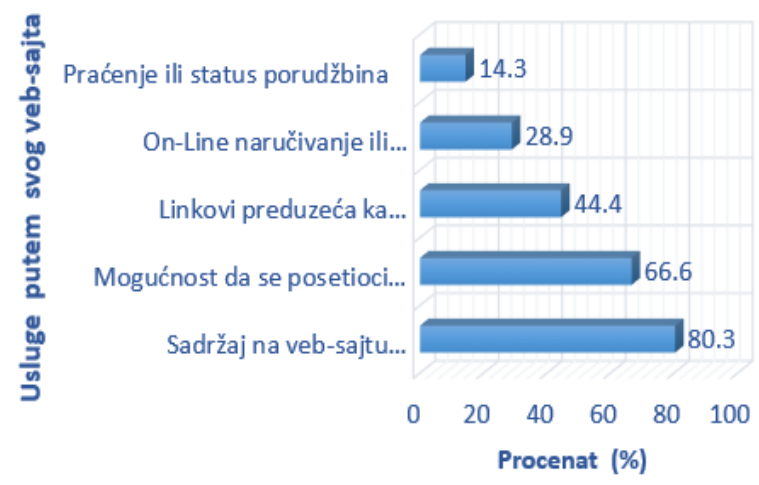

Slika 17. Mogućnost pružanja usluga od strane preduzeće posredstvom svog veb-sajta (\%).

Preduzeća posredstvom veb-sajta najčešće pružaju:

- Sadržaj na veb-sajtu prilagođen redovnim posetiocima $(79,3 \%)$. 
- Opis robe ili usluga, cenovnik $(86,2 \%)$.

- Mogućnost da se posetioci upoznaju sa proizvodima $(66,6 \%)$.

\subsubsection{Primena E-trgovina u preduzećima}

Tokom 2018. godine 42,3\% preduzeća u Republici Srbiji naručivalo je proizvode/usluge putem interneta, što čini povećanje od svega $0,4 \%$ u odnosu na 2017. godinu, a $0,9 \%$ u odnosu na 2016. godinu (Republički zavod za statistiku, 2019). Kada pogledamo strukturu preduzeća prema veličini, dobijamo sledeće rezultate:

- 40,3\% velikih preduzeća naručivalo je proizvode/usluge putem interneta.

- $37,4 \%$ srednjih preduzeća naručivalo je proizvode/usluge putem interneta.

- 43,6\% malih preduzeća naručivalo je proizvode/usluge putem interneta.

- $42,3 \%$ preduzeća naručivalo je proizvode/usluge putem interneta

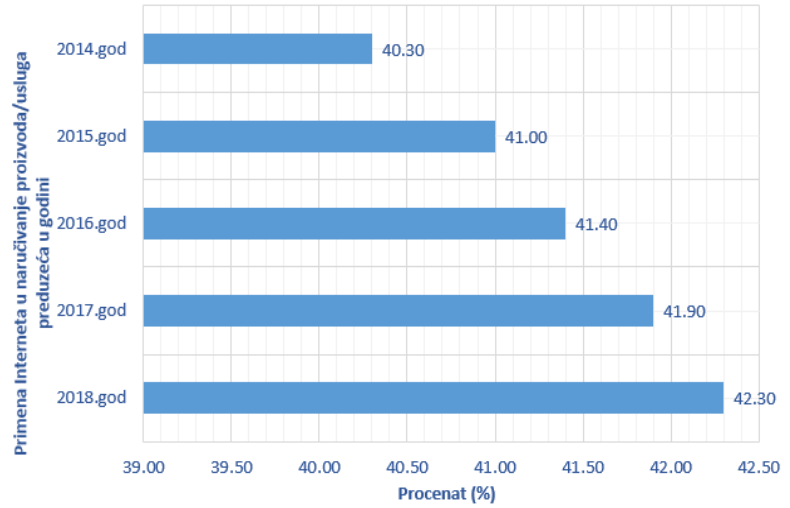

Slika 18. Pregled preduzeća koja su naručivala proizvode/usluge putem interneta (\%).

Rezultati istraživanja pokazuju da je samo $27,5 \%$ preduzeća tokom 2018. primalo porudžbine (izuzev imejl-porudžbina) putem interneta. 27,5\% preduzeća primalo je porudžbine putem interneta

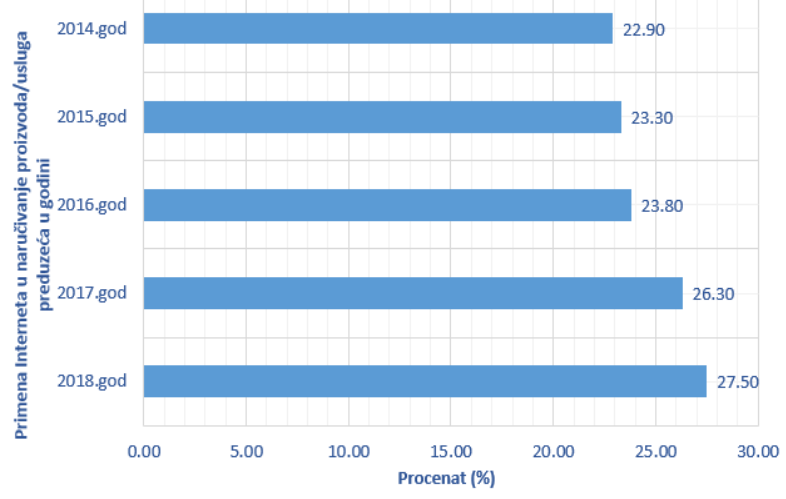

Slika 19. Pregled preduzeća koja su primala porudžbine putem interneta (\%).
Kada pogledamo strukturu preduzeća prema veličini, dobijamo sledeće rezultate:

- $28,5 \%$ velikih preduzeća primalo je porudžbine putem interneta.

- $28,7 \%$ srednjih preduzeća primalo je porudžbine putem interneta.

- $27,1 \%$ malih preduzeća primalo je porudžbine putem interneta.

Učešću dela ukupnog prometa koji je realizovan na osnovu porudžbina primljenih putem interneta preduzeća:

- "Manje od 24\%“ (63,8\% preduzeća).

- "Više od 24\%, a manje od 50\%" (13,1\% preduzeća).

- "Više od $50 \%$, a manje od $75 \%$ “ $(9,4 \%$ preduzeća).

- ,75 \% i više“ (13,7\% preduzeća).

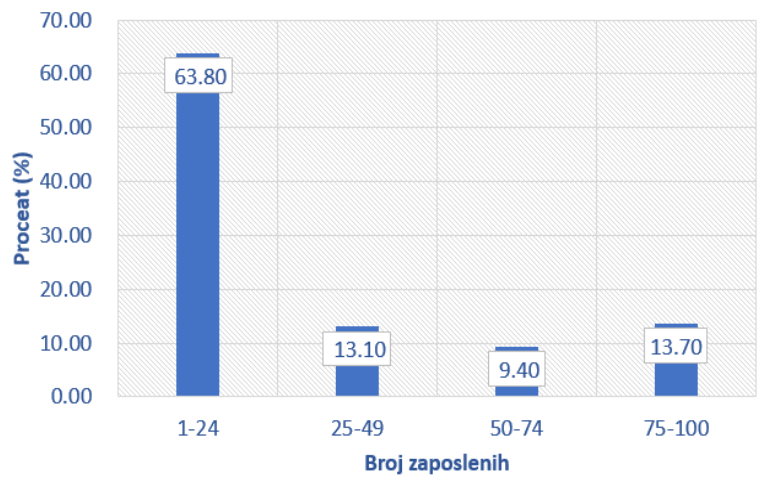

Slika 20. Učešće dela ukupnog prometa u 2018. godini, koji je realizovan na osnovu porudžbina primljenih putem interneta (\%).

\subsubsection{Primena društvenih mreža u preduzećima}

Društvene mreže su sve prisutnije i u poslovanju preduzeća. U prilog tome nam govore rezultati istraživanja koji pokazuju da je $47,4 \%$ preduzeća koristilo neku od društvenih mreža za potrebe poslovanja preduzeća.

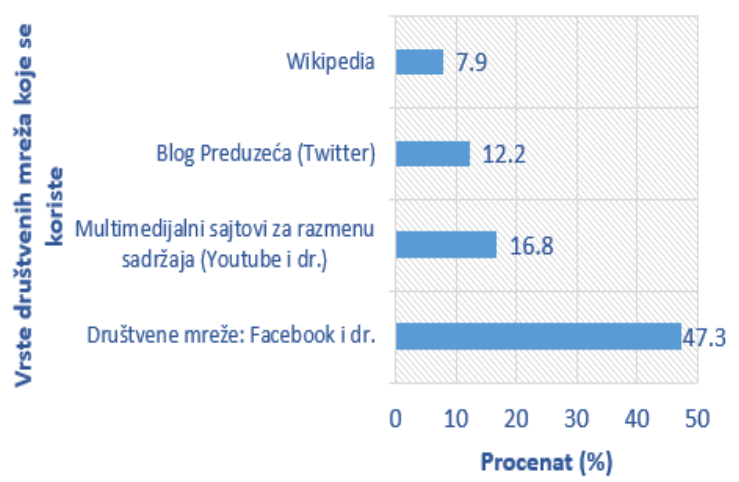

Slika 21. Pregled upotrebe društvenih mreža u preduzeću za potrebe poslovanja (\%). 


\subsubsection{Upotreba klaud servisa u preduzećima}

Usluge klaud servisa plaća putem interneta $21,9 \%$ preduzeća. Klaud servisi podrazumevaju IKT servise kojima se pristupa putem interneta radi upotrebe softvera, prostora za skladištenje podataka i sl. Servisi imaju sledeće karakteristike: nalaze se na serverima pružalaca usluga (provajdera); mogu da se upotrebljavaju na zahtev korisnika; plaćaju se na osnovu načina upotrebe, kapaciteta prostora.

Ukupno 21,9\% preduzeća plaća usluge klaud (engl. cloud) servisa.

\section{ANALIZA REZULTATA}

Prethodna analiza (Republički zavod za statistiku, 2019) pokazala je da gotovo $100 \%$ preduzeća u Srbiji ima računare i pristup internetu. U 2019. godini veb-sajt je imalo oko $83,6 \%$ preduzeća, pri čemu je prisutan neprekidan trend rasta ovog procenta od 2015. godine, kada je ono iznosilo $75,2 \%$. Upotreba ERP softvera, takođe, beleži trend rasta. Učešće preduzeća koja koriste CRM softver za analiziranje informacija o klijentima za potrebe marketinga je 2013. godine iznosilo 13,7\%, dok se 2016. godine ono nalazilo na nivou od $17,3 \%$. Procenat preduzeća u Republici Srbiji koja naručuju proizvode ili usluge putem interneta se u periodu od 2014-2018. godine kreće oko $40,3 \%-42,3 \%$, dok se procenat preduzeća koja primaju porudžbine (izuzev e-mail porudžbina) putem interneta kreće oko za 2014-2018. godinu kreće oko $22,9 \%-27,5 \%$, pri čemu se zapaža blagi trend rasta oba učešća.

U 2019.godini 21,9\% preduzeća plaćalo je usluge klaud servisa. Od $7.9 \%$ do $47,4 \%$ preduzeća je koristilo neku od društvenih mreža za potrebe poslovanja preduzeća.

U $35,8 \%$ preduzeća od 1 do $24 \%$ zaposlenih lica koristi prenosive uređaje za poslovne potrebe, dok u $29,8 \%$ preduzeća od 75 do $100 \%$ zaposlenih koriste prenosive uređaje za poslovne potrebe.

U 2019.godini 79,1\% preduzeća je koristilo mobilnu internet konekciju upotrebom prenosivih uređaja (smartfon, laptop, tablet...).

$\mathrm{Na}$ osnovu napred izvršene analize kretanja različitih pokazatelja upotrebe IKT u preduzećima u Srbiji može se zaključiti da je prisutna tendencija rasta primene IKT $\mathrm{u}$ poslovanju preduzeća. Doduše, neki aspekti poslovanja odlikuju se značajnom primenom IKT, dok u drugim upotreba ovih tehnologija još uvek nije zastupljena u značajnijoj meri. Podaci $i$ analize koji su prikazani u ovom radu, ukazuju na to da je Srbija po spremnosti za primenu IKT (infrastrukture, pristupačnosti i veština) na relativno visokom nivou, ali da je i pored toga na veoma niskom nivou po primeni IKT u poslovanju preduzeća. Toj kontradiktornoj situaciji doprinosi i činjenica da su u Srbiji u značajnom procentu zastupljeni poslovi koji su zasnovani na znanju, u odnosu na druge poslove, a u tome veliki udeo imaju novi poslovi u IKT sektoru, a posebno u sve jačoj softverskoj industriji, odnosno, industriji poslovnog softvera, čiji se proizvodi koriste u mnogim preduzećima širom sveta, ali nedovoljno u preduzećima u Srbiji. U 2019. godini mobilno oglašavanje je nadmašilo 200 milijardi dolara na globalnom nivou. Očekuje se da će dostići 400 milijardi dolara do 2023. godine. Predviđa se da će se utrošiti na mobilne digitalne oglase $80 \%$ globalne potrošnja.

Danas prvih pet tržišta predstavlja $85 \%$ svetske potrošnje na mobilne oglase. Očekuje se najbrži rast $u$ primene mobilnog oglašavanja $u$ Kini $i$ ubrzanog napredovanja svesti potrošača o primeni mobilnih internet ručnih uređaja (do $85 \%$ ). Sve veći broj kompanija (oglašivači I izdavači) podstiču ulaganja u strategije mobilnih uređaja.

Informaciono-komunikacione tehnologije su postale univerzalno dostupne. Međutim, i dalje je veoma izražen digitalni jaz između ekonomski razvijenih zemalja i zemalja u razvoju. U radu je opisan način merenja uticaja indeksa spremnosti za umrežavanje (NRI - The Networked Readiness Index). Nakon što se merenjem 62 parametra dobiju ocene svakog od stubova, prostim prosekom indikatora za svaki od stubova izračunavaju se podindeksi, da bi se konačna vrednost indeksa izvela iz proseka četiri podindeksa.

Podaci Svetskog ekonomskog foruma pokazuju da je Srbija po spremnosti za korišćenje IKT, napredovala za četrdeset jedno mesto, od 2011. godine, (od 138 ekonomije) kada joj je rang bio 93, a indeks 3,5 (na skali od 1 do 7 ) da bi joj u 2019. godini (od 121 ekonomija) rang bio 52 , a indeks 4,0 što se može videti u tabeli 5 . 
Tabela 5. Indeks spremnosti za primenu IKT (NRI) za Srbiju, u periodu 2010-2019. godine.

\begin{tabular}{|l|l|l|}
\hline $\begin{array}{l}\text { Godina } \\
\text { (Broj zemalja) }\end{array}$ & Rang & $\begin{array}{l}\text { Skor } \\
(1-7)\end{array}$ \\
\hline $2019(121)$ & 52 & - \\
\hline $2016(139)$ & 75 & 4.0 \\
\hline $2015(143)$ & 77 & 4.0 \\
\hline $2014(148)$ & 80 & 3.9 \\
\hline $2013(144)$ & 87 & 3.7 \\
\hline $2012(142)$ & 85 & 3.6 \\
\hline $2011(138)$ & 93 & 3.5 \\
\hline $2010(133)$ & 84 & 3.5 \\
\hline
\end{tabular}

\section{ZAKLJUČCI}

Istraživanja relevantnih institucija, pre svega Republičkog zavoda za statistiku, pokazala su da je prisutnost računara i računarskih mreža u preduzećima u Srbiji dostigla gotovo potpun obuhvat.

Zaključuje se da su IKT moćan pokretač uspešnih ekonomija, pri čemu imaju ključnu ulogu pri povećanje ekonomskog rasta. Predstavljaju dinamički faktor koji doprinosi modernizaciji javne uprave, ekonomskog i socijalnog razvoja relevantnih za postizanje širih ciljeva Evropa 2020.

$\mathrm{U}$ tom kontekstu, rad prikazuje snažnu povezanost između IKT-a, Indeksa mrežne spremnosti i konkurentnost. Razvijene zemlje prioritetno uvode inovacije u cilju povećanja svoje konkurentnosti dok zemlje u razvoju, posebno iz jugoistočne Evrope, ulažu napore da povećaju upotrebu IKT u cilju pokretanje ekonomskog rasta.

Republika Srbija prepoznaje ekonomski potencijal koji bi imalo stvaranje jedinstvenog digitalnog tržišta, u ovom trenutku treba jasno definisati prioritete i ciljeve, odrediti viziju digitalne ekonomije i uspostaviti pravni okvir za njen dalji razvoj.

Razvoj informacionog društva treba usmeriti ka iskorišćenju potencijala IKT za povećanje efikasnosti rada, ekonomski rast, veću zaposlenost i podizanje kvaliteta života svih građana Republike Srbije (Strategija razvoja informacionog društva u Republici Srbiji do 2020. godine, 2010). Jedan od prioriteta je integracija tehnologije sa tri ključne interesne grupe: pojedinci, preduzeća i vlade. Koraci koje treba preduzeti u pravcu povećanja digitalne konkurentnosti privrednih subjekata, a samim tim i zemlje su:

1. Elektronske komunikacije, gde su prioriteti: povećati investicije u razvoj IKT u svim fazama razvoja privrednih subjekata; otvoreni širokopojasni pristup zasnovan na optičkim vlaknima kao glavnoj tehnologiji za povezivanje korisnika, uključujući domaćinstva, čime se omogućavaju protoci od preko $100 \mathrm{Mb} / \mathrm{s}$; mobilni širokopojasni pristup kojim se omogućava pristup Internetu sa mobilnih uređaja i prenosnih računara nezavisno od lokacije na kojoj se korisnik nalazi; komunikaciona infrastruktura javnog sektora; uključiti građane Republike Srbije, što se posebno odnosi na uključenost socijalnih grupa sa posebnim potrebama, regionalni razvoj i jačanje lokalnih inicijativa.

2. E-uprava, e-zdravstvo i e-pravosuđe, gde su određeni sledeći prioriteti: elektronski identitet u uslugama javnog sektora; primena IKT u organima uprave i imaocima javnih ovlašćenja; primena IKT u sistemu zdravstvene zaštite; primena IKT u pravosuđu

3. IKT u obrazovanju, nauci i kulturi sa prioritetom na: razvojem znanja $i$ veština povezanih sa IKT i jačanjem uloge IKT u sistemu obrazovanja; pokloniti pažnju obrazovanju u oblasti IKT, zadržati stimulativnim merama ove stručnjake u zemlji; akademska računarska mreža; istraživanja i inovacije u oblasti IKT i digitalni sadržaji

4. Elektronska trgovina (e-trgovina) sa prioritetom na: uklanjanje normativnih prepreka za razvoj e-trgovine; razvijati digitalno podržan tržišni ambijent, kroz razvijanje ponude i tražnje digitalnih tehnologija; elektronski računi i elektronsko plaćanje; podsticanje razvoja eposlovanja; zaštita potrošača u e-trgovini i koordinacija razvoja e-trgovine.

5. Poslovni sektor IKT sa prioritetom na: povećati primenu IKT kako u velikim, tako i u malim i srednjim privrednim subjektima (MSP), da bi oni transformisali svoje poslovanje u pravcu povećanja produktivnosti i konkurentnosti; izgraditi preduzetničku digitalnu kulturu, kroz promovisanje digitalnih preduzetnika u društvu; koordinacijom i kooperacijom između javnog, privatnog i civilnog sektora; razvoj ljudskih resursa; stalnim ulaganjem $u$ istraživanje $i$ 
inovacije, da bi se potencijali koje donosi IKT iskoristili; razvoj startap i inovativnih kompanija; izvoz i prekogranični autsorsing; zaštita intelektualne svojine softvera i digitalnih sadržaja.

6. Informaciona bezbednost, gde imati prioritet na: odgovorima na izazove koje donosi IKT (novi aspekti bezbednosti, ugrožavanje privatnosti, tehnološka zavisnost, nedovoljna interoperabilnost i otvorena pitanja zaštite intelektualne svojine); unapređenje pravnog $\mathrm{i}$ institucionalnog okvira za informacionu bezbednost; zaštita kritične infrastrukture; borba protiv visokotehnološkog kriminala; naučnoistraživački i razvojni rad u oblasti informacione bezbednosti.

Digitalna ekonomija u Republici Srbiji nije dovoljno razvijena. To je jedan od razloga slabih izvoznih i razvojnih performansi zemlje. Da bi se to promenilo potrebno je uvođenje određenih korelacija u strategijama i sprovođenju ekonomske politike digitalne transformacije zemlje. Ako se poseduje odgovarajuća infrastruktura, ako građani imaju puno poverenje u IKT, ako postoje definisani odnosi između zainteresovanih strana onda se može izgraditi stabilna digitalna ekonomija. Mala i srednja preduzeća moraju prioritetno:

- Koristiti Internet kao kanal prodaje i komunikacije sa potrošačima i partnerima.

- Podsticati interesna udruživanja u oblasti etrgovine.

- Organizovano nastupati u sklopu svojih strukovnih ili drugih udruženja.
- Realizovati edukacija ključnih stejkholdera uz finansijsku pomoć društva za primenu ovog koncepta.

- Realizovati ubrzanu edukacija menadžmenta i zaposlenih radi podizanja konkurentnosti i potpunog prihvatanja koncepta e-poslovanja i e-trgovine.

- Koristiti konsultantska pomoć pri uvođenju inovacija u e-poslovanje i razvoju softverskih rešenja, savetodavnu pomoć za nabavku IT opreme i sl.

- U skladu razvojem informacionog društva koristiti subvencionisanje i kreditiranje za uvođenje koncepta e-poslovanja i e-trgovine.

Cilj digitalne ekonomije u globalnom okruženju nije samo da se omogući svakom pojedincu/građaninu pristup internetu, već da im pomogne da se snađu u digitalnom svetu (integrišu u društvo i poslovni svet). Kompjuteri, mobilni telefoni i digitalne tehnologije centralni su deo naših svakodnevnih života i mogu nam pomoći pri rešavanju mnogih izazova sa kojima se suočavamo, od sigurnosti na putevima i zdravijeg starenja do boljih javnih usluga i održivog razvoja.

Uticaj NRI-a na ostale makro faktore poput konkurentnosti, upravljanja, korupcija i druge oblasti mogu se ispitati. Zemlje se mogu grupisati u različite kategorije na osnovu broja stanovnika, tipa upravljanja (demokratija, autokratija, monarhija, itd.). Može se pretpostaviti da je lakše poboljšati NRI u manjim i nerazvijenim nego $u$ većim zemljama. Postoji ogroman potencijal za istraživanja u ovim oblastima.

\section{CITIRANI RADOVI}

A. Bruce-Lockhart (2016). What do we mean by 'governance'?. World Economic Forum. World Economic Forum. Preuzeto sa: https://www.weforum.org/agenda/2016/02/what-isgovernance-and-why-does-it-matter/

A Digital Single Market Strategy for Europe. (2015). Brussels: European Comision

Annual report 2012-2013. (2013).Canberra: Australian Government, Department of Broadband, Communications and the Digital Economy.

Bloomberg Businesswek. (2018). China Has Big Plans for Homegrown Chips. Bloomberg

Businessweek. Preuzeto sa: https://www.bloomberg.com/news/articles/2015-06-25/chinahas-big-plans-for-homegrown-chips

Crisan, D. A.-M. (2018). Innovation Performance Analysis for European Union Countries Focused on Modest Innovators: Romania and Bulgaria. Journal of Information Systems \& Operations Management, 12(1), 30-45. 
Digital economy rankings 2010 Beyond ereadiness A report from the Economist Intelligence Unit (2010). New York:by The Economist Intelligence Unit with The IBM Institute for Business Value.

Digital Sector Economic Estimates. (2016), Statistical Release, January 2016. London: GOV.UK, Department for Culture Media \& Sport, Digital Sector Economic Estimates.

Discussion Paper For International Seminar \#1 'Digital Economy Concept, Trends and Visions: Towards a FutureProof Strategy (2016). Moscow: World Bank Country Office, Moscow, Russia.

English Oxford Living Dictionaries. (2018). Dostupno na: https://www.oxfordlearnersdictionaries.com/

European Commission. (2018). Growth- SectorsDigital economy, Digital economy policy. Dostupno na: 11.02 .2020 .

European Commission (2017). Growth - Sectors - Digital economy. Dostupno na: https://ec.europa.eu/growth/sectors/digital-economy_en.

European Commission (2018). Growth - Sectors - Digital economy, The importance of the digital economy. Dostupno na: 11.02.2020.

European Commission (2018). Europe 2020 - Europe 2020 in a nutshell, Dostupno: 03.02.2020.

European Union (2014). Digital economy \& society, Digital agenda for Europe, Dostupno: 20.01.2018.

Fukuyama, F. (2016). Governance: What Do We Know, and How Do We Know It?. Annu. Rev. Polit. Sci., 19(1), 89-105.

Global Information Technology Report 2016. URL: http://reports.weforum.org/global-informationtechnologyreport-2016/preface/?doing_wp_cron=1543242577.9932959079742431640625 (Date of access: 26.01.2020).

Goethe University of Frankfurt (2014). Dostupno na: http://www.is-frankfurt.de/ [16. 01. 2020].

G20 Digital Economy Development and Cooperation Initiative (2016). Hangzhou: G20, 2016 China. 15. Information economy report 2015 (2015). Geneva: United Nations, UNCTAD/IER/2015.

Gupta, P., Prakash, S., \& Jayaraman, U. (2009). IT Infrastructure and its Management. Tata McGraw Hill Education.

Housley, R., \& Polk, T. (2001). Planning for PKl: best practices guide for deploying public key infrastructure. John Wiley \& Sons, Inc.

Imamović, H., Regodić, D., \& Grubor, G. (2014). The Implications of the Maturity Level of Strategic Alignment of ICT Systems Projects on Economic Criminality, XV Međunarodni naučni skup Sinergija 2014-Privredni kriminalitet i savremeno poslovanje, pp. 176-180, 02.12 .2014

Lann, S. (2011). IT Infrastructure Architecture-Infrastructure building blocks and concepts. Raleigh, NC, USA: Lulu Press Inc, 2011.

Lutovac, Z. (2016). Pristupačnost audiovizuelnog sadržaja osobama s invaliditetom u kontekstu ljudskih prava. Zbornik Matice sropske za društvene nauke Novi Sad, (4/2016), 159-160.

Matotek, M., Barać, I., Regodić, D. \& Grubor, G. (2015). Supply Chain Risk Management Using Software Tool. Acta Polytechnica Hungarica, doi: 10.12700/APH.12.4.2015.4.10.

Majstorović, M., Regodić, D., \& Grubor, G. (2016). Metamodel of a service-oriented business. Sinteza 2016, International scientific conference on ict and e-business related research, doi: 10.15308/Sinteza-2016. pp. 36-43, Univerzitet Singidunum, Beograd. 
Marković, V. (2016). Individualni preduzetnik pravni okvir poslovanja. Prvo izdanje. Beograd: Poslovni biro d.o.o.

Milenkovic, M. J., Brajovic, B., Milenkovic, D., Vukmirovic, D., \& Jeremic, V. (2015 ). Beyond the equal-weight framework of the Networked Readiness Index: a multilevel I-distance methodology. Sage Journals, 1120-1136.

Peeters, M. (2018), American Chamber of Commerce to the EU. Dostupno na: https://euagenda.eu/organisers/american-chamber-of-commerce-to-the-eu Preuzeto: 10.01.2020.

Pratipatti, S., \& Gomaa, A. (2019). A Longitudinal Analysis of the Impact of the Indicators in the Networked Readiness Index (NRI). Journal of International Technology and Information Management, 28(2).

PubMatic. (2019) 2020 Global Digital Ad Trends. https://pubmatic.com/wpcontent/uploads/2019/12/2020-Global-Digital-Ad-Trends.pdf

Regodić D., Regodić R. (2018), Performance and evaluation of the maturity of information technology, Conference: Menadžment 2018, Beograd, Volume: 1

Regodić, D., \& Stojanović M., (2016). The Improvement of the Inventory Process in the Company "Benlian Food" Niš by Applying the Pom-Qm 4.0 Software, Sinteza 2016, 10.15308/Sinteza-2016-257-264, pp, 257-264, Univerzitet Singidunum.

Regodić, D., \& Cvetković, D.( 2011). Automatizacija, proizvodni sistemi i računarski integrisana proizvodnja, Univerzitet Singidunum, Beograd, ISBN 978-86-7912-367-1

Republički zavod za statistiku. (2019). Upotreba informaciono-komunikacionih tehnologija u Republici Srbiji, ISSN 1820-9084, Beograd.

Savulescua, C. (2014). Czech Republic Dynamics of ICT development in the EU. 2nd Global Conference on Business, Economics. Management and Tourism, 30-31, Prague.

Soldić-Aleksić, J., \& Stankić, R. (2015). A Comparative Analysis of Serbia and the EU Member States in the Context of Networked Readiness Index Values. Economic Annals, 45-86.

Soumitra, D., \& Lanvin B. (2020). Insight report The Network Readiness Index 2019 Towards a Future-Ready Society. Washington D.C., USA : Portulans Institute

Spasojević, N. (2015). Specifičnosti e-uprave: Ekonomsko-Finansijske konsekvence. Economics, 3(1), 125-133.

Stanivuk, M. (2015). Intelektualni kapital u digitalnoj ekonomiji. Economic, 3(1), 135-147

Stojanovic, M., \& Regodić, D. (2017). The significance of the integrated multicriteria ABC-XYZ method for the inventory management process. Acta Polytechnica Hungarica, 14(5), 29-48

Stojanović, M., \& Regodić, D. (2016). Uticaj informaciono - komunikacionih tehnologija na ekonomski rast. Zbornik radova Univerziteta Sinergija, Bijeljina.

Strategija razvoja informacionog društva u Republici Srbiji do 2020. godine (2010), Sl. glasnik RS, $(51 / 2010)$

The Technology Governance Board [Online]. Preuzeto sa : https://tgb.iowa.gov/ [16. 01. 2020].

Vujin, V. (2012). Model IT Infrastrukture za E-obrazovanje. Beograd: FON

Zečević, A., Radović, J., \& Čudan A. (2019). Primena informaciono-komunikacionih tehnologija u preduzećima u zemljama evropske unije. UDC: 33 ISSN: 1450-863 X, Ekonomski horizonti, Septembar - Decembar 2019, Volumen 21, Sveska 3, pp. 281 - 294. 
Received for publication: $\quad$ 08.03.2020.

Revision received: $\quad 10.02 .2021$

Accepted for publication: $\quad$ 05.04.2021

Kako citirati ovaj rad? / How to cite this article?

Style - APA Sixth Edition:

Regodić, D., Matić, A., \& Regodić, R. (2021, 04 15). Prilog analizi digitalizacije poslovanja preduzeća u Srbiji. (Z. Čekerevac, Ur.) FBIM Transactions, 9(1), 120-136. doi:10.12709/fbim.09.09.01.12

Style - Chicago Sixteenth Edition:

Regodić, Dušan, Aleksandar Matić, i Radomir Regodić. 2021. „Prilog analizi digitalizacije poslovanja preduzeća u Srbiji." Urednik Zoran Čekerevac. FBIM Transactions (MESTE) 9 (1): 120-136. doi:10.12709/fbim.09.09.01.12.

Style - GOST Name Sort:

Regodić Dušan, Matić Aleksandar i Regodić Radomir Prilog analizi digitalizacije poslovanja preduzeća u Srbiji [Časopis] // FBIM Transactions / ur. Čekerevac Zoran. - Beograd : MESTE, 1504 2021. - 1 : T. 9. - str. 120-136.

Style - Harvard Anglia:

Regodić, D., Matić, A. \& Regodić, R., 2021. Prilog analizi digitalizacije poslovanja preduzeća u Srbiji. FBIM Transactions, 15 04, 9(1), pp. 120-136.

Style - ISO 690 Numerical Reference:

Prilog analizi digitalizacije poslovanja preduzeća u Srbiji. Regodić, Dušan, Matić, Aleksandar i Regodić, Radomir. [ur.] Zoran Čekerevac. 1, Beograd: MESTE, 1504 2021, FBIM Transactions, T. 9, str. 120-136. 